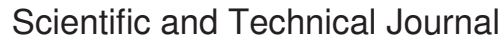 \\ Safety \& Defense 5(2) (2019) 28-34
}

\section{Military Law in the Republic of Poland}

\author{
Mariusz Antoni KAMIŃSKI \\ War Studies University, Warsaw, Poland; m.a.kaminski@akademia.mil.pl, \\ ORCID: 0000-0001-9395-9744
}

\begin{abstract}
The article presents an analysis of military law in the legal system of the Republic of Poland. On the one hand, it is a very specialized area of law, and on the other, it is a very extensive field regulated in several hundred national legal acts of varying importance (universally and internally binding), as well as by international law. The author attempts to organize the subject matter of military law and to specify its elements divided into subject-specific blocks. At the same time, in order to ensure a better understanding of the nature of military law, the article discusses the role of the Armed Forces of the Republic of Poland in times of peace, crisis, and war.

The author used critical analysis of literature on legal science and security sciences, and source materials: mainly acts of universally binding law (the Constitution, acts, and regulations), as well as acts of internally binding law (instructions, ordinances, resolutions, decisions, guidelines, and agreements of various state authorities).
\end{abstract}

Keywords: defense law, law, legal system, military law, national security law, security law

\section{Introduction}

In a democratic law-abiding state, armed forces are one of the most important elements of the national security system. Their primary task is to defend the independence and sovereignty of the state (by combating external threats), but nowadays, the military is increasingly being used for internal tasks. There is no doubt that, as a result, legal regulations concerning the principles of the functioning of armed forces are becoming particularly important.

In the legal system of the Republic of Poland, the set of legal norms regulating the basis for the functioning of the armed forces is referred to as military law. On the one hand, it is a very specialized field of law (applicable to a specific group - soldiers and civilian personnel of the armed forces) and, on the other hand, it is a very extensive field regulated in several hundred national legal acts of various importance (universally and internally binding) and in international law.
At the same time, military law is both a separate part of national security law (related to military security) and a part of the defense law of the Republic of Poland.

The aim of the article is to analyze the military law in the legal system of the Republic of Poland and to try to organize its subject matter. At the same time, in order to ensure a better understanding of the nature of military law, the article will discuss the role of armed forces in times of peace, crisis, and war.

The main research problem was formulated as the following question:

- What is the subject matter of military law and can its characteristic elements be distinguished by subject-specific blocks for practical purposes?

Due to the fact that military law issues are interdisciplinary in nature, I used both critical analysis of legal science literature and security sciences in my research. Moreover, 
I based my analysis on source materials: mainly acts of universally binding law (the Constitution, acts, and regulations), as well as acts of internally binding law (instructions, ordinances, resolutions, decisions, guidelines, and agreements of various state authorities).

\section{The role of armed forces in the state}

In the definition proposed by Waldemar Kitler, military law is "a set of legal norms governing the grounds for and the functioning of the armed forces, soldiers, and civilian personnel, and the relations between them and other national and international entities, as well as a set of special provisions for armed forces during states of emergency, mainly martial law (and war), criminal law, and disciplinary provisions in the military [own transl.]" [1, p. 168].

In order to properly understand the nature of military law and to indicate its scope, it is necessary to clarify the role of the armed forces in the state and their tasks in times of peace, crisis, and war.

The Armed Forces are defined as a specialized body of the state designed to protect and defend its interests by using it as a deterrent against aggression or, if necessary, to conduct armed combat until it achieves its stated political objective. From the point of view of organizational structures, they can be divided into regular and irregular armed forces, and from the point of view of the nature of the operations conducted - into operational forces and territorial defense forces and means, and from the point of view of the environment in which they conduct operations - into land forces, air forces, and navies [2, p. 121].

In the opinion of Bolesław Balcerowicz, the key to understanding of the place and role of the armed forces is to properly recognize and understand the relations between politics and its tools. In his opinion, politics uses certain means to achieve its objectives, three of which should be considered the most important: diplomatic, economic and military means. Among them, B. Balcerowicz considers diplomatic means (together with normative and psychosocial means) as the most important, followed by economic means, while military means are considered to hold third place (and constitute a kind of a reserve). This is because military forces should be used as a last resort (although sometimes it is decisive). Moreover, B. Balcerowicz points out that the role and significance of military power in politics (especially in foreign policy) are different in different states: peace, crisis, and war. During a war, military power definitely plays a primary role. During a crisis, the role of the armed forces is significant, but not necessarily decisive. In peacetime, however, the tasks related to support of the policy of the state, including the role of deterrence, come to the fore [3, pp. 27-29]. A similar point of view on the role of the armed forces is also presented by Ole Wæver and Barry Buzan [4, pp. 417-435].

Armed forces are supported by military intelligence. The intelligence has always assisted military operations. Actually, military intelligence is as old as war itself. As Jan Goldman noted, "military intelligence is an agency of the armed forces that obtains and analyzes and uses information of strategic or tactical military value information about the armed forces of another country that is useful in planning and conducting military policy or military operations" [5, kindle location 179].

As mentioned in previous considerations, the armed forces are a tool of the state that can be used both externally and internally. The basic and priority task of the Polish Armed Forces is to protect the sovereignty of the Polish state, its territorial integrity, and the inviolability of its borders. This is expressly stated in Article 26 of the Constitution of the Republic of Poland, which provides that "The Armed Forces of the Republic of Poland shall safeguard the independence and territorial integrity of the State, and shall ensure the security and inviolability of its borders" [6]. Thus, in the performance of their external function, the Polish Armed Forces serve to counteract aggression and eliminate military threats as well as to maintain peace and defend national sovereignty.

However, the armed forces also play an important role in ensuring the internal security of the state and thus perform their internal function. This is related, among others, to the evolution of threats in the security environment, especially the increase in the terrorist threat and the transformation of the contemporary dimension of terrorism. In the modern world, there is a growing tendency for the military to support both civil authorities and other uniformed services responsible for the internal security of the country [7, pp. 10-14].

The detailed tasks of the Polish Armed Forces in their internal function are specified in Article 3 (2) of the Act of 21 November 1967 on common defense duty, Journal of Laws of 2019 No 1541, the Armed Forces may take part in combat against natural disasters and elimination of their consequences, counter-terrorist and property protection activities, search and rescue operations or operations aimed to protect human health and life, clearing of explosives and hazardous materials of military origin from the land and their neutralization, as well as in performance of crisis management tasks [8]

As Grzegorz Sobolewski emphasized, the armed forces are an effective tool of the state intended for protection of society, maintaining national and state identity, and the preservation of sovereign authority. Thus, when defining the function of the armed forces in the system of national security, it can be assumed that its essence is an organized defense and protection against external and internal threats, and its effectiveness is expressed as an appropriate ratio of the protective and defensive potential given the scale of the existing threats [9, p. 35]. The constant evolution of the security environment means that the armed forces play an increasingly important role in combating new internal and external threats, such as cyber terrorism [10, pp. 23-25].

However, the Armed Forces should not play a leading or dominant role in providing assistance to civil authorities and other uniformed services. As W. Kitler noted, the role of the Polish Armed Forces in fulfilling its internal function should be supported and serviced, and military assistance is provided when there is an objective need for it. The military must not compete with civil institutions that are subordinated to government administration bodies or local governments, or 
even with commercial entities. Decisions about the use of the Polish Armed Forces are made when there is an urgent need and when specific actions exceeds the capabilities of the civil authorities, human life is endangered, the situation is of a crisis nature, when the legal order in the state and human health and life are endangered [11, p. 48].

\section{Subject matter of military law in the Republic of Poland}

The military law system in the Republic of Poland consists of legal acts of various importance. As far as national law is concerned, these are both the provisions of the Constitution of the Republic of Poland, acts (mainly in such fields of law as administrative, criminal, business, and labor law), and regulations (mainly of the Council of Ministers, the Prime Minister, and the Minister of National Defense). Additionally, the system is to a very large extent developed by normative acts of internally binding law, such as instructions (of the President of the Republic of Poland), ordinances (of the President of the Republic of Poland, the Prime Minister, and the Minister of National Defense), resolutions (of the Council of Ministers), decisions (of the Minister of National Defense), guidelines and agreements, orders, bylaws, regulations, and enforcement regulations. It is also possible to point to legal acts of other central states authorities and acts of local law issued by local military administration bodies [1, p. 171]. Of course, provisions of international law also apply to military law, and international humanitarian law for armed conflicts plays a special role in this respect [12, pp. 69-94].

Military law is a separate part of national security law and defense law that regulates an extremely important aspect of national defense. Its special position is emphasized especially by the provisions of the Constitution of the Republic of Poland. The relevant legal regulations can be found, i.a., in the main principles of the system of government (chapter I), freedoms, rights and obligations of the human being and citizen (chapter II), tasks of the legislative and executive authorities (chapters IV, V, and VI), and matters related to states of emergency (chapter XI) [13]. Although, as can be seen, these regulations are located in different parts of the Constitution, they are strongly interrelated and should be considered together, as indicated by verdicts of the Constitutional Tribunal, as well as the views of the doctrine of legal sciences and security sciences [14, p. 15].

In order to organize military law in terms of its subject matter, it can be divided into several subject-specific blocks:

1. legal and systemic issues (including leadership and supervision over the Armed Forces of the Republic of Poland and the powers of the supreme authorities of the state);

2. issues related to the functioning and organization of the Polish Armed Forces;

3. issues related to military service;

4. issues related to military discipline and the criminal liability of soldiers;

5. issues related to the role of the Polish Armed Forces in emergency situations;
6. issues concerning the equipment of the Polish Armed Forces and management of military property;

7. issues related to the stay of the Polish Armed Forces abroad and the presence of foreign troops on the territory of the Republic of Poland; and

8. issues related to military education and the training of soldiers.

The first group is legal and systemic issues, including the issue of authority and supervision over the Armed Forces of the Republic of Poland and the powers of the state's supreme authorities in this area. These are primarily constitutional regulations. This is a classic constitutional regulation, because in constitutional law, these powers very often belong to the organs of legislative and executive power [15, pp. 119-123].

It should be noted that the Polish Armed Forces is the only uniformed formation to which the provisions of the Constitution of the Republic of Poland refer directly, which additionally emphasizes their special role in the state.

The aforementioned Article 26 of the Constitution, apart from the main mission of the Armed Forces, also indicates that "The Armed Forces shall observe neutrality regarding political matters and shall be subject to civil and democratic control." According to Article 134, the President of the Republic of Poland is the supreme commander of the Armed Forces of the Republic of Poland, and in peacetime, he exercises this authority through the Minister of National Defense. In addition, the President appoints the Chief of General Staff and the commanders of the branches of the Armed Forces, and during war, at the request of the Prime Minister, appoints the Commander-in-Chief of the Armed Forces. Moreover, pursuant to Article 136, in the event of a direct external threat to the state, the President, at the request of the Prime Minister, orders a full or partial mobilization and use of the Armed Forces to defend the Republic of Poland. With regard to the Council of Ministers, Article 146 (4) of the Constitution indicates that its scope of competence includes ensuring the external and internal security of the state and general management in the field of defense. As regards legislative power, pursuant to Article 95(2), the Sejm (lower chamber of the parliament) of the Republic of Poland exercises control over the activities of the Council of Ministers (and thus also of the Minister of National Defense) and, pursuant to Article 116, decides on behalf of the Republic of Poland on the state of war and the conclusion of peace. [6]

Apart from constitutional solutions, the issue of leadership of and supervision over the Armed Forces of the Republic of Poland and the powers of the supreme authorities of the state is also regulated in several acts, e.g. the Act on universal defense duty [16], the Act on the office of the Minister of National Defense [17], the Act on departments of government administration [18], the Act on martial law and the powers of the Supreme Commander of the Armed Forces [19], as well as in a resolution concerning the Rules of Procedure of the Sejm of the Republic of Poland (e.g. in the scope of parliamentary control powers) [20].

Another group of issues dealt with by military law concerns the functioning and organization of the Polish Armed 
Forces. They include issues of leadership and command of the Armed Forces and organizational units of the military (including, but not limited to, the tasks and competencies of the Chief of the General Staff, the General Commander of the Branches of the Armed Forces, the Operational Commander of the Branches of the Armed Forces, the Commander of the Territorial Defense Forces, and the Commander-in-Chief of the Armed Forces in wartime); the organization of the Polish Armed Forces (including the division into the branches of Armed Forces - the Land Forces, the Air Force, the Navy, the Special Forces, and the Territorial Defense Forces); organization and functioning of the Military Police, the Military Counterintelligence Service, and the Military Intelligence Service; organization and functioning of military authorities and military administration; organization of personnel reserves administration; control in the Armed Forces; military diplomacy and organization of military attaché's offices; and cooperation of the Armed Forces with other state services and authorities. This broad subject matter is regulated by many acts, among which the following should be mentioned in particular: the Act on the universal defense duty, the Act on the office of the Minister of National Defense, the Act on the Military Police and military enforcement bodies [21], the Act on the Military Counterintelligence Service and the Military Intelligence Service [22], the Act on signs of the Armed Forces of the Republic of Poland [23], the Act on the protection of the state border [24], the Act on anti-terrorist operations [25], the Act on crisis management [26], the Act on martial law, and the competences of the Commander-in-Chief of the Armed Forces [27].

The next block of issues covers military service. These include, among others, the obligation to perform military service as part of the general defense duty; alternative service; professional military service; the rights and obligations of soldiers; the service relationship; models for the conduct of military service; appointments to senior military ranks and official positions; social and economic guarantees for soldiers (including soldiers' remuneration, awards, and benefits, Armed Forces' accommodation, health care, pensions, and disability benefits); apoliticism and professional ethics of soldiers; compensation benefits associated with military service; the labor code in military service; application of the code of administrative procedure in military service; status of Armed Forces' veterans; military grades and titles, as well as medals and decorations; military etiquette; and protection of personal data in the Armed Forces. The main legal acts in this field include the Act on the military service of professional soldiers [28], the Act on the universal defense duty, the Act on accommodation of the Armed Forces [29], the Act on pensions for professional soldiers and their families [30], the Act on alternative service [31], the Act on veterans of operations abroad [32], the Act on the protection of personal data [33], the Act on the protection of classified information [34], the Act on measures of direct coercion and firearms [35], the code of administrative procedure [36], and the labor code [37].

The next group of issues concerns military discipline and the criminal liability of soldiers. The key issues in this area include military criminal law (including in particular offences specified in the Criminal Code and matters subject to the jurisdiction of military courts - criminal and criminal-fiscal proceedings, and misdemeanors); disciplinary liability of soldiers (including the principles of disciplinary liability, subjects in disciplinary proceedings, the role of disciplinary ombudsmen, the catalogue of sanctions, preventive measures, and the disciplinary procedure); organization and functioning of military courts; participation of the Military Police in activities intended to enforce military discipline; and the activities of military legal counsels and legal advisers. These issues are regulated, among others, by the Act on military discipline [38], the Criminal Code [39], the Code of Criminal Procedure [40], the Executive Criminal Code [41], the Fiscal Penal Code [42], the law on the system of military courts [43], and the Law on the public prosecutor's office [44].

Military law also regulates a group of issues related to the role of the Polish Armed Forces in emergency states: martial law, state of emergency, and state of natural disaster. These are primarily constitutional solutions, including the entire Chapter XI of the Constitution. Pursuant to Article 229 of the Constitution of the Republic of Poland, "in the case of external threats to the State, acts of armed aggression against the territory of the Republic of Poland or when an obligation of common defense against aggression arises by virtue of international agreement, the President of the Republic may, at the request of the Council of Ministers, declare a state of martial law in a part of or upon the whole territory of the State" and pursuant to Article 230 "in the case of threats to the constitutional order of the State, to security of the citizenry or public order, the President of the Republic may, on request of the Council of Ministers, introduce for a definite period no longer than 90 days, a state of emergency in a part of or upon the whole territory of the State. Extension of a state of emergency may be made once only for a period no longer than 60 days and with the consent of the Sejm." [45] On the other hand, the prerequisites for the introduction of the state of a natural disaster are laid down in Article 232 of the Constitution: "in order to prevent or remove the consequences of a natural catastrophe or a technological accident exhibiting characteristics of a natural disaster, the Council of Ministers may introduce, for a definite period no longer than 30 days, a state of natural disaster in a part of or upon the whole territory of the State. An extension of a state of natural disaster may be made with the consent of the Sejm". Detailed regulations concerning the role of the Armed Forces of the Republic of Poland during the three emergency states are contained mainly in three acts: the Act on martial law and the powers of the Commander-in-Chief of the Armed Forces, the Act on the state of emergency [46], and the Act on the state of natural disaster [47].

The next group of issues is related to the equipment of the Polish Armed Forces and the management of military property. The important issues in this group include financing and modernization of the Armed Forces; regulations on equipping the Armed Forces with weapons and military equipment and other materials related to military service; the 
organization and functioning of the Military Property Agency (AMW); the principles of management of the housing and boarding contained in the resources at the disposal of the AMW; and the principles of management of the State Treasury property at the disposal of the AMW. It should be emphasized that the budget of the Ministry of National Defense (from which the Polish Armed Forces are financed) is subject to special regulations. Article 7(1) of the Act of 21 May 2001 on reconstruction and technical modernization and financing of the Polish Force Armed, Journal of Laws of 2019 No 1453, provides for a progressive increase in the expenditures related to the financing of defense needs amounting to not less than $2 \%$ of the GDP in 2018 and 2019 , up to $2.5 \%$ of the GDP in 2030 [48]. As a result, the budget of the Ministry of National Defense in 2018 amounted to over PLN 41.5 billion [49, p. 2]. Detailed regulations concerning the equipment of the Polish Armed Forces and management of military property are included in the following acts: the Act on reconstruction and technical modernization and financing of the Polish Armed Forces, the Act on the Military Property Agency [50], the Act on public finance [51], the Act on real estate management [52], the Act on foreign trade in goods, technologies and services of strategic importance for national security [53], and the Act on public procurement law [54]. The important role of the budget law should also be emphasized.

In connection with Poland's membership in the North Atlantic Treaty Organization and the participation of the Polish Military in foreign military missions, the regulations concerning the stay of the Polish Armed Forces abroad are an important issue in military law. It is regulated primarily by the Act on the rules of use or stay of the Armed Forces of the Republic of Poland outside the borders of the state. On the other hand, the issue of the stationing in the territory of Poland of NATO troops and armed forces of other countries (both within the framework of joint exercises and maneuvers and for longer periods) is regulated by the Act on the rules of stay of foreign troops on the territory of the Republic of Poland and on the rules of their movement through this territory [55].

Military education and the training of soldiers are also a separate issue in military law. The military education system in the Republic of Poland currently comprises five higher education institutions subordinated to the Minister of National Defense. Three of them - the War Studies University in Warsaw, the Military University of Technology in Warsaw, and the Polish Naval Academy in Gdynia - were established on the basis of these statutes. The General Tadeusz Kościuszko Military University of Land Forces in Wrocław and the Polish Air Force Academy in Dęblin were established on the basis of regulations. All military universities and academies operate on the basis of the provisions of the Act on higher education and science and, at the same time, they have the status of military units. The military education system also comprises three non-commissioned officer schools (for the Army, the Navy, and the Air Force) established under the regulation of the Minister of National Defense, as well as eleven training centers (including the Signals and Information Technology Training Center in Zegrze, the Artillery and
Armament Training Center in Toruń, the Military Centre for Medical Education in Łódź, and the Military Training Centre for Military Police in Mińsk Mazowiecki). The principles of the education of soldiers are regulated in the Act on the service of professional soldiers and in the Regulation of the Minister of National Defense on the education of professional soldiers.

To conclude the discussion on the subject matter of military law, it should be emphasized that these issues are also covered by the norms of international law. In particular, international humanitarian law on armed conflicts plays an important role, regulating, among others, the legal status of persons in armed conflicts, the treatment of prisoners of war, civilians and vulnerable persons, as well as the prohibitions and restrictions on the use of means of armed combat, and the principles of conduct of combat (wartime necessity, humanitarianism, and proportionality). Issues concerning the general prohibition on the use of force in international relations and legal cases of use of armed forces, such as individual or collective self-defense, the authorization of the UN Security Council to use force, a national liberation war, a humanitarian intervention, and so-called brotherly aid, i.e. military intervention at the request of a legal government fighting against rebel or secessionist forces in its territory are also very important [56, pp. 123-140].

\section{Conclusions}

Given the important role of armed forces in a state in times of peace, crisis, and war, a set of legal norms that form military law is one of the key elements of national security. On the other hand, however, it is difficult to consider military law as a separate branch of law (within the meaning of the traditional division into branches of law applied in legal sciences in Poland). The main reason for this is that the scope of military law is vast (several hundred of various acts of universally binding and internally binding law) and includes legal regulations from various branches of law, such as constitutional law, administrative law, criminal law, business law, labor law, public international law, and others.

Consequently, military law derives from many branches and fields of law, constituting a separate field of law that regulates the basis for the functioning of the armed forces in a state. For practical purposes, it is useful to divide the scope of military law into subject-specific groups. One option is the division recommended in this article into legal and systemic issues, issues related to the functioning and organization of the Polish Armed Forces, issues related to military service, issues related to military discipline and criminal liability of soldiers, issues related to the role of the Polish Armed Forces in emergency states, issues related to equipment of the Polish Armed Forces and management of military property, issues related to the stay of the Polish Armed Forces abroad and the presence of foreign troops on the territory of the Republic of Poland, and issues related to military education and training of soldiers. It seems that such a division contributes to a better organization of the military law in the Republic of Poland. 


\section{References}

[1] Kitler, W., (2018). Organizacja bezpieczeństwa narodowego RP. Aspekty ustrojowe, prawno-administracyjne i systemowe. Toruń: Wydawnictwo Adam Marszałek

[2] Kaczmarek J. and Łepkowski W. and Zdrodowski B (eds). (2008). Słownik terminów z zakresu bezpieczeństwa narodowego, Warszawa: Akademia Obrony Narodowej.

[3] Balcerowicz, B. (2010). Siły zbrojne w stanie pokoju, kryzysu, wojny. Warszawa: Wydawnictwo Naukowe Scholar.

[4] Wæver, O. and Buzan, B. (2016). After the Return to Theory: The Past, Present, and Future of Security Studies. In Contemporary Security Studies, A. Collins (ed.), 4th edition, pp. 417-435, Oxford: Oxford University Press.

[5] Goldman, J. (2011). Words of Intelligence. Kindle Edition. Lanham-Toronto-Plymouth: Scarecrow Press.

[6] The Constitution of the Republic of Poland of 2 April 1997, Dz.U. of 1997, No. 78, item 483, http://www.sejm.gov.pl/prawo/konst/angielski/kon1.htm, access: 30.09.2019.

[7] Schnabel, A. and Krupanski, M. (2012). Mapping Evolving Internal Roles of the Armed Forces, Geneva: Geneva Centre for the Democratic Control of Armed Forces.

[8] The Act of 21 November 1967 on common defense duty, Dz.U. of 2019 No 1541, http://prawo.sejm.gov.pl/isap.nsf/DocDetails. xsp?id=WDU19670440220, access: 30.09 .2019 .

[9] Sobolewski, G. (2013). Siły Zbrojne RP w zarządzaniu kryzysowym. Aspekt narodowy i międzynarodowy. Warszawa: Akademia Obrony Narodowej.

[10] Farwell, J.P. and Rohozinski, R. (2011). The New Reality of Cyber War. Survival, 53(1), (pp. 23-40).

[11] Kitler, W. (2017). Rola sił zbrojnych w państwie. In W.Kitler, D.Nowak, and M.Stepnowska (eds), Prawo wojskowe, pp. 37-50. Warsaw: Wolters Kluwer.

[12] Vité, S. (2009). Typology of armed conflicts in international humanitarian law: Legal concepts and actual situations. International Review of the Red Cross, 91(873), (pp. 69-94).

[13] The Constitution of the Republic of Poland of 2 April 1997, Dz.U. of 1997, No. 78, item 483, http://www.sejm.gov.pl/prawo/konst/angielski/kon1.htm, access: 30.09.2019.

[14] Wołpiuk, W. (1998). Siły Zbrojne w regulacjach Konstytucji RP. Wydawnictwo Scholar, Warsaw.

[15] Barnett, H. (2019). Constitutional and Administrative Law, 13th edition. Taylor \& Francis Ltd.

[16] The Act of 21 November 1967 on common defense duty, Dz.U. of 2019 No 1541, http://prawo.sejm.gov.pl/isap.nsf/DocDetails. xsp?id=WDU19670440220, access: 30.09 .2019 .

[17] The Act of 14 December 1995 on the office of the Minister of National Defense, Dz. U. 2019 No. 196, http://prawo.sejm.gov.pl/isap.nsf/ DocDetails.xsp?id=WDU19960100056, access: 30.09 .2019

[18] The Act of 4 September 1997 on departments of government administration, Dz. U. 2019 No. 945, 1248, 1696, 2170, http://prawo. sejm.gov.pl/isap.nsf/DocDetails.xsp?id=WDU19971410943, access: 30.09 .2019

[19] The Act of 11 September 2003 on martial law and the competences of the Commander-in-Chief of the Armed Forces, Dz. U. 2017 No. 1932, http://prawo.sejm.gov.pl/isap.nsf/DocDetails.xsp?id=WDU20021561301, access: 30.09.2019

[20] The Rules of Procedure of the Sejm of the Republic of Poland, M.P. 2019 No. 1028, http://prawo.sejm.gov.pl/isap.nsf/DocDetails. xsp?id=WMP19920260185, access: 30.09 .2019

[21] The Act of 24 August 2001 on the Military Police and military enforcement bodies, Dz. U. 2019 No. 518, 730, http://prawo.sejm.gov.pl/ isap.nsf/DocDetails. $x$ sp?id=WDU20011231353, access: 30.09 .2019

[22] The Act of 9 June 2006 on the Military Counterintelligence Service and the Military Intelligence Service, Dz. U. 2019 No. 687, http://prawo.sejm.gov.pl/isap.nsf/DocDetails.xsp?id=WDU200 61040709, access: 30.09 .2019

[23] The Act of 19 February 1993 on signs of the Armed Forces of the Republic of Poland, Dz. U. 2019 No. 1351, http://prawo.sejm.gov.pl/ isap.nsf/DocDetails.xsp?id=WDU19930340154, access: 30.09.2019
[24] The Act of 12 October 1990 on the protection of the state border, Dz. U. 2019 No. 1776, http://prawo.sejm.gov.pl/isap.nsf/DocDetails. $x$ sp?id=WDU19900780461, access: 30.09 .2019

[25] The Act of 10 June 2016 on anti-terrorist operations, Dz. U. 2019 No. 796, http://prawo.sejm.gov.pl/isap.nst/DocDetails.xsp?id=WDU20160000904, access: 30.09.2019

[26] The Act of 26 April 2007 on crisis management, Dz. U. 2019 No. 1398, http://prawo.sejm.gov.pl/isap.nsf/DocDetails.xsp?id=WD U20 070890590, access: 30.09.2019

[27] The Act of 11 September 2003 on martial law and the competences of the Commander-in-Chief of the Armed Forces, Dz. U. 2017 No. 1932, http://prawo.sejm.gov.pl/isap.nsf/DocDetails.xsp?id=WDU20021561301, access: 30.09.2019

[28] The Act of 11 September 2003 on the military service of professional soldiers, Dz. U. 2019 No. 330, 730, 1726, http://prawo.sejm.gov.pl/ isap.nsf/DocDetails.xsp?id=WDU20031791750, access: 30.09 .2019

[29] The Act of 22 June 1995 on accommodation of the Armed Forces, Dz. U. 2018 No. 2356, 2019 No. 1726, http://prawo.sejm.gov.pl/isap. nsf/DocDetails.xsp?id=WDU19950860433, access: 30.09.2019

[30] The Act of 10 December 1993 on pensions for professional soldiers and their families, Dz. U. 2019 No. 289, 730, 1635, 1726, http:// prawo.sejm.gov.pl/isap.nsf/DocDetails.xsp?id=WDU19940100036, access: 30.09 .2019

[31] The Act of 28 November 2003 on alternative service, Dz. U. 2018 No. 885 , http://prawo.sejm.gov.pl/isap.nsf/DocDetails.xsp?id=WDU20032232217, access: 30.09.2019

[32] The Act of 19 August 2011 on veterans of operations abroad, Dz.U. 2019 No. 1569, 1726, http://prawo.sejm.gov.pl/isap.nsf/DocDetails. xsp?id=WDU20112051203, access: 30.09 .2019

[33] The Act of 10 May 2018 on the protection of personal data, Dz. U. 2019 No. 1781, http://prawo.sejm.gov.pl/isap.nsf/DocDetails. xsp?id=WDU20180001000, access: 30.09 .2019

[34] The Act of 5 August 2010 on the protection of classified information, Dz. U. 2019 No. 742, http://prawo.sejm.gov.pl/isap.nsf/DocDetails. xsp?id=WDU20101821228, access: 30.09 .2019

[35] The Act of 24 May 2013 on measures of direct coercion and firearms, Dz. U. 2019 No. 2418, http://prawo.sejm.gov.pl/isap.nsf/DocDetails.xsp?id=WDU20130000628, access: 30.09 .2019

[36] The Act of 14 June 1960 the code of administrative procedure, Dz. U. 2018 No. 2096, z 2019 No. 60, 730, 1133, http://prawo.sejm.gov.pl/ isap.nsf/DocDetails.xsp?id=WDU19600300168, access: 30.09 .2019

[37] The Act of 26 June 1974 the labor code, Dz. U. 2019 No. 1040, 1043, 1495, http://prawo.sejm.gov.pl/isap.nsf/DocDetails.xsp?id=WDU19740240141, access: 30.09 .2019

[38] The Act of 9 October 2009 on military discipline, Dz. U. 2019 No. 1508, 2020, http://prawo.sejm.gov.pl/isap.nsf/DocDetails.xsp?id=WDU20091901474, access: 30.09.2019

[39] The Act of 6 June 1997 the Criminal Code, Dz. U. 2019 No. 1950 , 2128, http://prawo.sejm.gov.pl/isap.nsf/DocDetails.xsp?id=WDU19 970880553, access: 30.09 .2019

[40] The Act of 6 June 1997 the Code of Criminal Procedure, Dz.U. 2018 No. 1987, http://prawo.sejm.gov.pl/isap.nsf/DocDetails.xsp?id=WD U19970890555, access: 30.09.2019

[41] The Act of 6 June 1997 the Executive Criminal Code, Dz. U. 2019 No. 676, 679, 1694, 2070, http://prawo.sejm.gov.pl/isap.nsf/DocDetails.xsp?id=WDU19970900557, access: 30.09 .2019

[42] The Act of 10 September 1999 the Fiscal Penal Code, Dz.U. 2018 No. 1958, http://prawo.sejm.gov.pl/isap.nsf/DocDetails.xsp?id=WDU19990830930, access: 30.09.2019

[43] The Act of 21 August the law on the system of military courts, Dz. U. 2019 No. 2216, http://prawo.sejm.gov.pl/isap.nsf/DocDetails. $x$ sp?id=WDU19971170753, access: 30.09 .2019

[44] The Act of 28 January 2016 the Law on the public prosecutor's office, Dz. U. 2019 No. 740, http://prawo.sejm.gov.pl/isap.nsf/DocDetails.xsp?id=WDU20160000177, access: 30.09 .2019

[45] The Constitution of the Republic of Poland of 2 April 1997, Dz.U. of 1997, No. 78, item 483, http://www.sejm.gov.pl/prawo/konst/angielski/kon1.htm, access: 30.09.2019.

[46] The Act of 21 June 2002 on the state of emergency, Dz. U. 2017 No. 1928, http://prawo.sejm.gov.pl/isap.nsf/DocDetails.xsp?id=WDU20021130985, access: 30.09.2019 
[47] The Act of 18 April 2002 on the state of natural disaster, Dz.U. 2017 No. 1897, http://prawo.sejm.gov.pl/isap.nsf/DocDetails.xsp?id=WDU20020620558, access: 30.09 .2019

[48] The Act of 21 May 2001 on reconstruction and technical modernization and financing of the Polish Force Armed, Dz.U. of 2019 No 1453, http://prawo.sejm.gov.pl/isap.nsf/DocDetails.xsp?id=WDU20190001453, access: 30.09.2019.

[49] Ministerstwo Obrony Narodowej. (2018). Podstawowe informacje o budżecie resortu obrony narodowej na 2018 r., http://mon. gov.pl/d/pliki/dokumenty/rozne/2018/02/budzet2018.pdf, access: 30.09.2019

[50] The Act of 10 July 2015 on the Military Property Agency, Dz. U. 2018 No. 2308,2019 No. 492, 1214, 2020, http://prawo.sejm.gov.pl/isap. nsf/DocDetails.xsp?id=WDU20150001322, access: 30.09.2019

[51] The Act of 27 August 2009 on public finance, Dz. U. 2019 No. 869, 1622, 1649, 2020, http://prawo.sejm.gov.pl/isap.nsf/DocDetails. xsp?id=WDU20091571240, access: 30.09 .2019

[52] The Act of 21 August 1997 on real estate management, Dz. U. z 2018 No. 2204, 2348, 2019 No. 270, 492, 801, 1309, 1589,
1716, 1924, 2020, http://prawo.sejm.gov.pl/isap.nsf/DocDetails. xsp?id=WDU19971150741, access: 30.09 .2019

[53] The Act of 29 November 2000 on foreign trade in goods, technologies and services of strategic importance for national security, Dz. U. 2019 No. 953, 1214, http://prawo.sejm.gov.pl/isap.nst/DocDetails. $x$ sp?id=WDU20001191250, access: 30.09 .2019

[54] The Act of 29 January 2004 on public procurement law, Dz. U. 2019 No. 1843 , http://prawo.sejm.gov.pl/isap.nsf/DocDetails.xsp?id=WDU20040190177, access: 30.09.2019

[55] The Act of 17 December 1998 on the rules of stay of foreign troops on the territory of the Republic of Poland and on the rules of their movement through this territory, 2014 No. 1510, $2019 \mathrm{r}$. No. 1726, http://prawo.sejm.gov.pl/isap.nsf/DocDetails.xsp?id=WDU19981621117, access: 30.09.2019

[56] Milik, P. (2017). Legalne użycie sił zbrojnych w świetle prawa międzynarodowego. In W.Kitler, D.Nowak, and M.Stepnowska (eds), Prawo wojskowe (pp. 123-142). Warszawa: Wolters Kluwer. 